\title{
ЛЮДИНОЗНАВЧЕ ОСМИСЛЕННЯ СОБОРНОСТІ УКРАЇНИ
}

\author{
Ярослав КАЛАКУРА \\ Державний вищий навчальний заклад \\ “Київський наџіональний університет імені Тараса Шевченка", \\ кафедра архівознавства та спеиіальних галузей історичної науки, \\ вул. Володимирська 60, 01033, Київ, Украӥна \\ e-mail:kalajar@ukr.net \\ DOI: 10.15330/gal.32.198-204 \\ ORCID: 0000-0002-8598-9019
}

\begin{abstract}
На основі аналізу української історіографії 1991-2018 рр. висвітлюється методологія $і$ сутність антропологічного підходу в дослідженні Соборності Украӥни, обтрунтовується переміщення уваги з конкретних подій і документів на їх учасників і твориів, на людей, задіяних у прочесах. Виділено три етапи історіографії Соборності: периий - 1991-2004 рр.; другий - між Помаранчевою революиією $і$ Революиією Гідності і третій - сучасний. Відстежено домінуючі тендениї дослідження проблеми, зокрема: перехід від висвітлення Соборності як Акту Злуки до трактування ії як тривалого і транзитного процесу; Соборність стала об'єктом міждисичилінарних досліджень; застосування ичивілізаційного та антропологічного підходу до осмислення Соборності і перехід від студіювання історії подій до історї̈ людей. Виокремлено три сегменти об'єкту людинознавчого погляду на проблему: ідейні натхненники, організатори і учасники соборницького проиесу; носії соборницької ідеї; дослідники Соборності. Висловлені пропозищї та рекомендащіі щуодо подальшого дослідження Соборності, утвердження державної та духовної єдності украӥнського суспільства.

Ключові слова: антропологічний підхід, людинознавчий вимір, історіографія, УНР, ЗУНР, Акт Злуки, соборність Украӥни, соборницький процес.
\end{abstract}

Багаторічний досвід дослідження Соборності України засвідчує, що пізнати і осмислити iii належним чином можна лише у координатах історичної антропології, тобто того сегменту історичної науки в іiі сучасному, постмодерністському розумінні, для якого пріоритетним об’єктом пізнання виступають не стільки безпосередні події і явища, які здебільшого вже з'ясовані, скільки їх творці і учасники, тобто люди. Актуальність означеної проблеми зумовлюється кількома чинниками. По-перше, не дивлячись на те, що людина - творець і найбільша цінність, участь конкретних людей в українському соборницькому процесі, цей аспект ще не отримав належного висвітлення в історичних дослідженнях. По-друге, антропологічний поворот історичної науки об'єктивно диктує необхідність подальшого опрацювання методології людинознавчого пізнанням в контексті цивілізаційної теорії, подолання негативних наслідків комунізації історичного знання. I, по-третє, проблеми соборності України перебувають в епіцентрі фальсифікацій та спотворень, передусім з боку російської історіографії, залишаються об’єктом різного роду маніпуляцій суспільною свідомістю. Ці та інші чинники висувають означену проблему в число актуальних завдань історичної науки і практичної діяльності щодо зміцнення єдності і соборності українського народу.

Ряд питань антропологічного підходу уже знайшов висвітлення у низці праць ${ }^{1}$, автори яких висвітлюють його сутність і частково торкаються методологічних засад людинознавчих досліджень. На важливість означеної проблематики вказано і в окремих студія ${ }^{2}$, безпосередньо

\footnotetext{
${ }^{1}$ Гошуляк І. Тернистий шлях до соборності (від ідеї до Акту Злуки). Київ : ІПіЕД, 2009. 467 с. ; Павлишин О. Обєднання УНР і ЗУНР : політико-правовий аспект (кінець 1918-перша половина 1919 р.). Вісник Львівського університету, 2002. Вип. 37. С. 327-349 ; Соборність як чинник українського державотворення / упорядн. Р. Пиріг. Київ : ІІУ НАНУ, 2009. 229 с. ; Шляхи та механізми консолідації українського суспільства, утвердження ідеалів соборності, свободи та демократії. Київ : КНЕУ, 2012. 294 с.

${ }_{2}^{2}$ Великочий В., Савчук Б. Українська історіографія про значення і наслідки Акту злуки УНР і зУНР 22 січня 1919 рр. Історія. Філософія. Релігієзнавство. 2008. № 1. С. 43-48 ; Калакура Я. С. Соборність
} 
присвячених історіографії соборності України. Мета пропонованої статті полягає в тому, щоб, спираючись на напрацювання попередників, з'ясувати специфіку людинознавчого осмислення Соборності України як тривалого процесу утвердження державної і духовної єдності суспільства, розкрити роль людського чинника у самому соборницькому процесі та його дослідженні, показати значення Соборності для людини, збереження і захисту цілісності етнічної території українського народу.

В умовах антропологічного повороту гуманітарних наук, генераційного підходу, який дедалі ширше утверджується в історичній науці, пріоритетним об'єктом дослідження, в тому числі й історичного, виступає людина, iï особистість як найбільша цивілізаційна цінність, іiі життєдіяльність у різних сферах суспільного розвитку, включаючи націо- і державотворення.

Людинознавчиий вимір має й сама українська соборність. Як засвідчують провідні вчені, українці за антропологічним складом однорідніші, ніж, скажімо, німці чи італійці, не говорячи вже про московитів. Ідея української соборності грунтується на генетичному корінні, носить природний і транзитний характер, вона передавалася від покоління до покоління і на всіх етапах історії наштовхувалась на спротив ворогів, зацікавлених у розмиванні єдності українства, доказом чого $є$ й нинішня війна РФ проти України.

Об’єкт людинознавчого погляду на Соборність у координатах історіографії має три виміри: ідейні натхненники, організатори і учасники соборницького процесу, люди, котрі користуються його наслідками і працюють на підтримку та захист Соборності i, нарешті, дослідники проблеми, їх науковий доробок. Соборність не абстрактне поняття. Це, передусім, люди українці, мешканці українських земель на Сході і Заході, на Півночі і Півдні, громадяни нашої держави і українці у світі. Це і $є$ одна велика соборна українська родина.

Не заглиблюючись у лінгвістику, все ж варто зазначити, що на відміну від російської імперської свідомості, де соборність дотепер пов'язується із “собиранием земель”, передусім чужих, свідченням чого і є путінська анексія АРК, окупація частини Донбасу і провокації в Азовському морі, в українській традиції - соборність - це єдність людей, духовна цілісність України. Багато хто пам'ятає роман Олеся Гончара “Собор". Так от, Собор - це наш храм, духовний символ, єдність наших душ, нашої історичної пам’яті, нашого майбутнього. Сакральності цього храму, нашій Соборності, іiі духовності неминуче служитиме об'єднана Православна церква України, яка отримала Томос на автокефалію. Як зазначає ії митрополит блаженніший Епіфаній, вона утверджуватиме у суспільстві любов, а не ворожнечу і ненависть. У зв'язку з цим згадалась думка Любомира Гузара: Україна не ділиться на Схід і Захід, вона ділиться на тих, хто iï любить, і хто іï не любить.

У лексиконі українських мислителів концепт “соборність” виокремився ще в середині XIX ст., а генетично він сягає щонайменше княжих часів Києворуської і Галицько-Волинської держав. Змістовно це поняття наповнювалося і збагачувалося в козацько-гетьманську добу, а політично почало викристалізовуватися на межі XIX-XX ст., коли звернення до досвіду минулого набувало особливої актуальності та гостроти у зв'язку з новим етапом українського національно-визвольного і державницького руху. Українська історіографія, якщо не рахувати поодиноких праць істориків діаспори 1920-1980-х рр., досліджує проблему Соборності фактично 28 останніх років, адже в совєтські часи було накладене табу навіть на сам термін “соборність”. Ї̈̈ започаткували кілька статей 1989-1991рр., поштовхом до яких стали відзначення 50-річчя так званого “возз'єднання” західноукраїнських земель з УРСР, утворення Народного Руху України, Української республіканської партії на чолі з Левком Лук'яненком, інших національно-демократичних об'єднань, Живий ланцюг Соборності 21 січня 1990 р., відтак Декларація про державний суверенітет і Акт проголошення незалежності України. Велику роль у світоглядному та методологічному переозброєнні постсовєтських істориків відіграли маловідомі джерела та діаспорна історіографія.

України як концепт новітньої історіографії. Історична пам'ять : наук. зб. Полтава, 2015. Вип. 33. С. 116 125 ; Реєнт О. П. Соборність України як наукова проблема і виклик часу. Історія України : маловідомі імена, подї, факти. Київ, 2005. Вип. 29. С. 31-39. 
У новітній історіографії Соборності можна виділити три етапи: перший - 1991-2004рp.; другий - між двома революціями - Помаранчевою і Революцією Гідності і третій - сучасний, який триває. У нас сформувалася ціла плеяда дослідників проблеми, на жаль деякі уже відійшли у світ вічності: Ярослав Дашкевич, Олександр Карпенко, Іван Курас, Степан Макарчук, Май Панчук, Іван Рибалко, Юрій Сливка та ін. Плідно працюють над цією проблематикою Богдан Андрусишин, Владислав Верстюк, Володимир Великочий, Іван Гошуляк, Ярослав Грицак, Олександр Добжанський, Іван Дробот, Орест Красівський, Станіслав Кульчицький, Микола Кугутяк, Микола Литвин, Олег Павлишин, Степан Павлюк, Іван Патриляк, Руслан Пиріг, Ігор Райківський, Олег Рафальський, Олександр Реєнт, Володимир Сергійчук, Валерій Смолій, Валерій Солдатенко, Ігор Соляр, Ігор Цепенда, Михайло Юрій та ін.

Якщо говорити про змістовний вимір опублікованих праць, а їх понад 600 , то можна виділити щонайменше три важливих тенденції нагромадження знань. Перша - це перехід від висвітлення Соборності як події, пов'язаної з ухваленням Акту Злуки, до трактування iї як тривалого, транзитного процесу, який не завершився й продовжується сьогодні. Друга - соборність, як наукова проблема, з урахуванням енергетичного бачення набула міждисциплінарного характеру, в її осмисленні поряд з істориками беруть участь політологи, правознавці, філософи, етнологи, економісти, демографи, психологи, культурологи, географи. I третя - найбільш нова. Нині дослідження соборності розгортається на засадах цивілізаційного та антропологічного підходу і переходу від студіювання історії подій до історії людей, супроводжується подоланням негативних наслідків комунізації науки, формаційного і партійно-класового трактування історичного процесу.

3 погляду антропології, Соборність грунтується на спадкоємності усіх поколінь борців за волю і самоствердження України, яку Тарас Шевченко визначив як кровну і генетичну єдність “мертвих, живих, і ненарожденних". Наші предки і їх нащадки упродовж віків освоювали і закладали цілісність етнічної території України, захищали і відстоювали ії неподільність, забезпечували безперервність української історії, зберігали і плекали рідну мову як головний ідентифікатор нації, сформували етнонаціональну ідентичність українців, унікальність їх характеру, ментальності, культури, освіти, науки та духовності, християнські цінності, почуття нескореності та нездоланності українського духу, єдності цивілізаційних устремлінь української нації. Символічною метафорою Соборності проникнутий наш Національний гімн України із його закликом стати на захист у “бій кривавий від Сяну до Дону”.

Тож перед історичною наукою і гуманітаристикою загалом постало винятково актуальне завдання дати відповідь, якою мірою наша соборність $€$ творінням людей і для людей, хто ці Люди, які закладали ідейні підвалини соборницького руху, будували його фундамент i забезпечили реалізацію в новітній історії. Багато з цих імен, безумовно, відомі, але їх мільйони, усіх не назвеш, адже мова йде про 30 поколінь наших одноплемінників. Це київські, переяславські, чернігівські, волинські і галицькі князі - Володимир Великий, Ярослав Мудрий, Володимир Мономах, Роман Мстиславич, Данило Галицький, це наші славні гетьмани - Петро Сагайдачний, Богдан Хмельницький, Іван Виговський, Петро Дорошенко, Іван Мазепа та інші. Це наші духовні Пастері, носії християнських цінностей і моральні авторитети, насамперед Григорій Сковорода, галицькі будителі - провідники "Руської трійці”, діячі Київської громади, Тарас Шевченко, Михайло Драгоманов, Іван Франко, Леся Українка, Михайло Грушевський, Симон Петлюра, Свген Коновалець, Степан Бандера, Роман Шухевич і т. д. Це підпільники ОУН і вояки УПА, українські шістдесятники і дисиденти - Василь Стус, В'ячеслав Чорновіл, Левко Лук'яненко, брати Горині, Герої Помаранчевої революції і Революції Гідності, Небесної сотні і антитерористичної операції.

Більшість істориків схиляються до думки про те, що прологом Соборності, головною об’єднуючою і консолідуючою постаттю наддніпрянців, слобожанців, галичан, волинян, буковинців і закарпатців був Тарас Шевченко та його творчість. Він став духовним батьком, опікуном і символом незламності української нації. Його портрети висіли в кожній селянській оселі між іконами святих, а проникливі слова “Обніміться ж, брати мої, молю вас, благаю!” сприймалися як заповіт для кожного свідомого українця. На час Першої світової війни і Української революції на всіх українських землях склався своєрідний культ Т. Шевченка, чий образ уособ- 
лював прагнення українського народу до свободи, соборності та національної державності і справляв колосальний вплив на революційність мас, їх національну свідомість, спонукав українців Сходу і Заходу до спільних дій братання.

Новітня історіографія має чітку відповідь на питання, в чому значення рубежу XIX$\mathrm{XX}$ ст. для українського соборницького руху. По-перше, в тому, що стараннями найвидатнішого нашого історика Михайла Грушевського та його львівської сторичної школи побачили світ перші томи “Історії України-Руси", проникнуті ідеєю окремішності нашого народу, цілісності його земель і спільністю великої мети як національної ідеї. Уже після Акту злуки вчений оприлюднив дуже важливу думку: "Нарід наш висловив свою волю, щоб Україна була одна, Східня і Західня, Наддніпрянська і Наддністрянська, оден край і оден народ, одно тіло й душа, і нема чого копирсатися в другорядних відмінах сих двох частин нашої єдиної вітчизни...”. Завдяки усвідомленню спільної історії наші прадіди приходили до розуміння того, що українці - один народ. А знати правдиву історію дуже важливо для самоідентифікації. Не випадково, Ф. Ніцше застерігав, що той народ, який сприймає трактування свої історії очима сусіда, ніколи не виживе. По-друге, уже тоді заявили про себе перші українські політичні партії, зокрема: Українська радикальна партія у Львові та Революційна українська партія у Харкові. Так от, один із лідерів УРП Іван Франко закликав координувати дії галицьких і наддніпрянських українців, а для цього: "Ми мусимо навчитися чути себе Українцями - не галицькими, не буковинськими Українцями, а Українцями без офіціяльних кордонів. I се почуте не повинно у нас бути голою фразою, а мусить вести за собою практичні консеквенції"4. А організатор РУП М. Міхновський у “Самостійній Україні” наголошував: “... Одна, єдина, нероздільна, вільна, самостійна Україна від Карпатів аж по Кавказ",.

Звертаючись до соборницьких подій сторічної давності, історики дедалі більше говорять не лише про Акт Злуки та Універсал Соборності, але й дошукуються відповіді на питання: кому конкретно належала тоді головна місія у Злуці двох гілок одного народу, роз'єднаного імперською політикою Росії та Австро-Угорщини, хто ініціював і проводив перемовини про об’єднання двох українських держав, які постали на розвалинах метрополій, хто опрацьовував Передвступний договір, хто створював проект Універсалу про Акт злуки і зачитував його текст у ті буремні дні, i, зрештою, хто благословив його.

Історики встановили, що ідея Соборності набула нового звучання в добу Української революції і державотворення 1917-1921 pp., а процес безпосередніх консультацій і перемовин щодо можливого об'єднання обох українських держав був започаткований на початку осені 1918 р. при Павлу Скоропадському з ініціативи Української Національної Ради на чолі 3 Євгеном Петрушевичем. Соборницьку позицію галичан активно підтримували лідери відомого першо-листопадового зриву у Львові Дмитро Вітовський, Степан Горук, Петро Бубела та ін. Гетьман зустрічався 3 представниками ЗУНР Осипом Назаруком і Володимиром Шухевичем, які висловилися за об'єднання і отримали запевнення, що для допомоги галичанам буде надіслано полк січовиків $Є$. Коновальця. Через декілька днів до гетьмана відправилась офіційна делегація у складі заступника міністра закордонних справ ЗУНР буковинця Теодота Галіпа та Івана Поповича, але поки вони добиралися до Києва, вже була підписана відома федераційна грамота з білою Росією.

У другій половині листопада ЗУНР направила нову місію у складі Лонгина Цегельського і Дмитра Левицького, яка зупинилася у Фастові, де на короткий час знаходилась столиця Директорії УНР. У так званому петлюрівському вагоні (до речі, тепер це "Музей-вагон Злуки УНР та ЗУНР”) 1 грудня 1918 р. вони й підписали Передвступний договір про наміри об'єднати населення і території обох утворень в одній державі. Дмитро Вітовський - на той час уже державний секретар ЗУНР - негайно повідомив про це керівництво УНР. Від імені Директорії підписи поставили Опанас Андрієвський, Володимир Винниченко, Симон Петлюра і Федір

\footnotetext{
${ }^{3}$ Грушевський М. С. Галичина і Україна. Твори : y 50 m. Т. 1. Львів : Світоч, 2002. С. 380.

${ }^{4}$ Франко І. Одвертий лист до галицької української молодежі. Зібрання творів : у $50 \mathrm{~m}$. Т. 45. Київ : Наук. думка, 1986. С. 405.

${ }^{5}$ Міхновський М. Самостійна Україна. Київ : Діокор, 2002. С. 21.
} 
Швець, а від уряду ЗУНР - Василь Стефаник (очільник), Лонгин Цегельський, Дмитро Левицький, Андрій Шмігельський, Тимотей Старух. Важливо зазначити, що Всенародні збори українців Закарпаття під головуванням Михайла Брайщака теж ухвалили рішення про з'єднання із соборною Україною. Саме Фастівський договір, який започаткував процес об'єднання УНР та ЗУНР, 3 січня 1919 р. був ратифікований Українською Національною Радою в Станіславі спеціальною ухвалою "Про злуку Західноукраїнської Народної Республіки з Українською Народною Республікою”. Президент ЗУНР Свген Петрушевич наголошував, що по лінії об’єднання не було між нами двох думок, але проглядалися розбіжності щодо механізму реалізації договору та його перспектив. Галичани найбільше побоювались, щоб лідери Директорії не пішли на угоду з російськими більшовиками.

По-справжньому людський вимір мали урочистості 22 січня 1919 р. в Києві, присвячені ухваленню та оприлюдненню Універсалу на підтримку Ухвали УНРради ЗУНР від 3 січня 1919 р. про об'єднання українських держав, багатолюдна маніфестація на майдані св. Софії. Саме тут член Директорії УНР Федір Швець зачитав Універсал про Злуку, його в різних місцях проголосили чотири читці, щоб тисячі присутніх почули, а архієпископ Агапіт відправив подячний молебень і звернувся українською мовою зі словами: “Я молюся й прошу Бога про те, щоб разом з національним об'єднанням двох народів Бог послав нам і єднання духовне”. На другий день Семен Вітик як голова Трудового конгресу зробив доповідь на урочистому засіданні, на якому було ратифіковано Акт Злуки. Виступаючи після цього заступник голови Української Національної Ради ЗУНР Лев Бачинський, який очолював офіційну делегацію у складі 36 осіб, зазначив: "Ми приходимо до вас, бо природа сама велить нам разом жити і вмирати. Бо ми брати”. Краще не скажеш!

Чимало дослідників не йдуть далі цих урочистостей, не вникають в антропологію подальших подій, які відбувалися після Універсалу Директорії про об'єднання. Мова йде про учасників опрацювання та схвалення низки законодавчих актів щодо форми і змісту державної влади в об’єднаній Україні, прийняття Закону про громадянство УНР і ЗООУНР та інших актів, про персональний склад управлінських органів. Нерідко автори обмежуються тим, що називають прізвища деяких міністрів та керівників управлінь в урядах, очолюваних В. Чехівським та С. Остапенком, зокрема О. Безпалка, А. Крушельницького, В. Темницького, О. Назарука та ін. Маємо мало відомостей про участь галичан та буковинців у діяльності дипломатичних місій, про рядових службовців державного апарату.

Майже всі дослідження Актів Злуки побудовані на позитиві. I це, очевидно, правильно. Але принципи об'єктивності та антропологічного підходу орієнтують історика підходити системно, персоніфікувати не тільки симпатиків Соборності України, але й зовнішніх та внутрішніх її ворогів, назвати імена тих персонажів, які були проти і доклали не мало зусиль, щоб зашкодити єднанню українського народу. Хто вони? Усіх не перерахуєш, але декілька відомих прізвищ все ж варто назвати. У війні проти незалежності УНР фактично спільним фронтом виступили адепти Білої і Червоної Росії. 3 одного боку Корнілов, Денікін, Врангель, а 3 другого вожді російського більшовизму і їх агенти в Харкові та інших містах України, включаючи й Східну Галичину, де діяли осередки комуністичної партії: Ленін, Троцький, Сталін, Свердлов, Ворошилов, Орджонікідзе, Фрунзе, Будьонний, Квірінг, П'ятакові, Артем, Затонський, Раковський, Антонов-Овсієнко, Криленко та ін. Це вони були диригентами повалення Директорії, окупації України, проголошення спочатку так званої УСРР, а відтак Галицької соціалістичної радянської республіки. Проти Злуки українських держав виступили лідери відновленої Речі Посполитої - Свержинський, Дашинський, Пілсудський, Морачевський та ін. Не без їх участі була знищена ЗУНР. Не залишились осторонь і державні діячі Угорщини та Румунії.

$€$ ще одна "нечиста сила" - внутрішня, яка завадила підкріпити Акт злуки конкретними діями. Це залишки малоросійства, москвофільства, австрофільства у свідомості багатьох тогочасних політиків, брак національної ідентичності українців Сходу і Заходу, взаємна недовіра і підозри, які Російська і Австро-Угорська імперії насаджували і підігрівали упродовж століть у суспільній свідомості наддніпрянців і галичан, формуючи відчуття “іншого" як “ворога". Хоч це й окрема тема, але вона дотична до антропології, особливо з погляду ментальності. 
Підсумовуючи висловлені тут підходи до людинознавчого виміру української Соборності, важливо ще раз підкреслити, що вона $є$ творінням людей для людей. Сьогодні ми ще далеко не знаємо тих мільйонів Людей, які закладали ідейні підвалини соборницького руху, будували його фундамент і забезпечили реалізацію в новітній історії і в цьому наш борг перед суспільством і майбутніми поколіннями. Важливо також наголосити, що Соборність України це, як кажуть математики, величина постійна, а для українських істориків завжди актуальна проблема. Соборність перебувала і залишається сьогодні в епіцентрі загроз, ідеологічних маніпуляцій Кремля, який під прикриттям парадигми "рускій мір”, “одін народ”, “общая історія”, “каноніческая територія" тощо, ще і ще раз публічно демонструє, що Росія не відмовилась від імперських зазіхань, вона була і залишається ворогом незалежності і соборності України. Соборність має не тільки національний, але й громадянський і політичний виміри. Звичайно, іiі осердям були й залишаються українці материкової України та майже 20 млн. зарубіжних українців. Водночас єдність і соборність українського суспільств багато в чому залежить і від представників національних меншин, які проживають в Україні і є їі громадянами.

Ось чому Соборність - це наша спільна справа і найбільша сила, яка потребує реальної підтримки, неухильного відстоювання і захисту, оскільки в ній один із чинників нашого майбутнього. Звідси - останнє. Історики, представники інших галузей гуманітаристики покликані об'єднатися навколо наповнення людським змістом понять “соборність України”, “українська соборність”, “соборність української культури і ментальності”, пошуку і обгрунтування оптимальної моделі та шляхів утвердження соборної України як самостійної, цілісної, територіально неподільної, демократичної європейської держави в умовах інтеграційних та глобалізаційних процесів. Потрібна також додаткова аргументація Соборності не тільки як ціннісного, духовнополітичного явища в житті української нації і держави, але й як закономірного процесу, що охоплює всю багатовікову історію України і є невіддільним від боротьби за ії самостійність, а його утвердження відбувається на основі осмислення історичної пам'яті, спільних інтересів українського соціуму, єдиного інформаційного простору. На всеукраїнському тлі єдності може розглядатися й так звана "регіональність" в контексті децентралізації влади, але не дезінтеграції України.

Українські гуманітарії покликані своїми працями розвивати і утверджувати це високе почуття Соборності, адже воно $є$ в генетичному коді кожного українця, з ним він народжується, але в декого цей ген залишається в ембріональному стані або зазнав мутації, а тому потребує допомоги для свого визрівання та самоствердження.

\title{
HUMAN REASONS ASSESSMENT OF THE UNITY OF UKRAINE
}

\author{
Yaroslav KALAKURA \\ Taras Shevchenko National University of Kyiv, \\ Department of Archival Studies and Specialties of Historical Science, \\ Volodymyrska St., 60, 01033, Kyiv, Ukraine \\ e-mail:kalajar@ukr.net
}

\section{Summary}

The aim is to analyze the latest Ukrainian historiography from the point of view of its specificity human comprehension of the Unity of Ukraine as a long process of approval state and spiritual unity of society, elucidation of the role of the human factor in itself unity process and its research, as well as the significance of the Unity for human.

On the basis of the application of a complex of methods of analysis of Ukrainian historiography 19912018 years highlights the methodology and the nature of the anthropological approach to the study of the Unity Ukraine, substantiates the shift of attention from specific events and documents to their participants and creators, on people involved in the processes. Highlighted three stages of historiography of the Unity: the first 1991-2004 years; the second - between the Orange Revolution and the Revolution of Dignity and the thirdmodern.

The dominant trends in the study of the problem are monitored, in particular: the transition from the illumination of the Unity as the Unification Act to interpreting it as a long process and transit; Unity became the object of interdisciplinary research; application of civilization and anthropological approach to comprehension 


\section{4}

of the Unity and the transition from studying the history of events to the history of people. Singled out three segments of the object of a human-oriented view of the problem: ideological inspiration, organizers and participants of the unity process; carriers of the unity idea; researchers of the Unity.

Expressed suggestions and recommendations on the further study of the Unity, the establishment of the state and spiritual unity of Ukrainian society, drawn attention to the need to fill the human meaning of "the unity of Ukraine", "Ukrainian unity", "the Unity of Ukrainian culture and mentality", search and study the optimal model and ways of practical assertion of the united Ukraine as an independent one, integral, territorially indivisible, a democratic European state in terms of integration and globalization processes.

Keywords: anthropological approach, human studies dimension, historiography, Ukrainian National Republic (UNR), The Western Ukrainian People's Republic (ZUNR), Reunion Act, the unity of Ukraine, unity process.

\section{REFERENCES}

Velykochyi V., Savchuk B. Ukrainska istoriohrafiia pro znachennia i naslidky Aktu zluky UNR i ZUNR 22 sich $\neg$ nia 1919 rr. Istoriia. Filosofiia. Relihiieznavstvo. 2008. № 1. S. 43-48. [in Ukrainian]. Ukrainian].

Hoshuliak I. Ternystyi shliakh do sobornosti (vid idei do Aktu Zluky). Kyiv : IPiED, 2009. 467 s. [in

Hrushevskyi M. S. Halychyna i Ukraina. Tvory : u 50 t. T. 1. Lviv : Svitoch, 2002. 592 s. [in Ukrainian].

Kalakura Ya. S. Sobornist Uk $\neg$ rainy yak kontsept novitnoi istoriohrafii. Istorychna pamiat : nauk. zb. Poltava, 2015. Vyp. 33. S. 116-125. [in Ukrainian].

Mihnovskyi M. Samostiina Ukraina. Kyiv, 2002. 76 s. [in Ukrainian].

Pavlyshyn O. Obiednannia UNR i ZUNR : polityko-pravovyi aspekt (kinets 1918-persha polovyna 1919 r.). Visnyk Lvivskoho universytetu. 2002. Vyp. 37. S. 327-349. [in Ukrainian].

Reient O. P. Sobornist Ukrainy yak naukova problema i vyklyk chasu. Istoriia Ukrainy : malovidomi imena, podii, fakty. Kyiv, 2005. Vyp. 29. S. 31-39. [in Ukrainian].

Sobornist yak chynnyk ukrainskoho derzhavotvorennia / uporiadn. R. Pyrih. Kyiv : IIU NANU, 2009. 229 s. [in Ukrainian].

Shliakhy ta mekhanizmy konsolidatsii ukrainskoho suspilstva, utverdzhennia idealiv sobornosti, svobody ta demokratii. Kyiv : KNEU, 2012. 294 s. [in Ukrainian].

Franko I. Odvertyi lyst do halytskoi ukrainskoi molodezhi. Zibrannia tvoriv : u 50 t. T. 45. Kyiv : Nauk. dumka, 1986. 767 s. [in Ukrainian]. 